\title{
Inferior Pancreatico-Duodenal Artery
}

National Cancer Institute

\section{Source}

National Cancer Institute. Inferior Pancreatico-Duodenal Artery. NCI Thesaurus. Code C32786.

A blood vessel arising from the superior mesenteric artery and connecting to the superior pancreatico-duodenal artery that supplies blood to the pancreas and duodenum. 